\title{
NILAI KECERNAAN BEBERAPA BAHAN PAKAN DALAM PENCERNAAN IKAN TAMBAKAN (Helostoma temminckii)
}

Hidayat Djajasewaka*) dan Evi Tahapari")

\begin{abstract}
ABSTRAK
Penelitian nilai kecernaan untuk berbagai bahan pakan ikan tambakan (Helostoma temminckii) dilakukan selama 12 hari di Laboratorium Basah Nutrisi, Sukamandi.

Tujuan penelitian ini adalah untuk mendapatkan nilai kecernaan protein, lemak, abu dan karbohidrat dari bahan baku pakan tepung ikan, bekatul, tepung pollar, tepung hydrilla dan tepung nitella pada ikan tambakan. Penelitian ini menggunakan metode Watanabe dengan campuran $1 \% \mathrm{Cr}_{2} \mathrm{O}_{3}$ dalam pakan sebagai internal marker. Ada lima bahan pakan perlakuan yaitu: 30\% tepung ikan, 30\% bekatul, 30\% tepung pollar, 30\% tepung hydrilla dan 30\% tepung nitella yang masing-masing dicampur dengan $70 \%$ pakan standar. Bobot awal ikan tambakan 9,25 g/ekor dengan padat tebar 30 ekor/60 L. Hasil penelitian menunjukkan bahwa nilai kecernaan tepung ikan dan tepung hydrilla lebih baik dibandingkan dengan bahan pakan lainnya $(\mathrm{P}<0,05)$. Tepung ikan dan tepung hydrilla dapat digunakan sebagai bahan pakan dalam formulasi pakan ikan tambakan.
\end{abstract}

ABSTRACT: The apparent digestibility of several feedstuffs in kissing gouramy (Helostoma tem minckii). By: Hidayat Djajasewaka and Evi Tahapari.

Study on the value of digestibility of various diets is required for formulation of quality feed for Helostoma temminckii. The digestibility values of protein, carbohydrate, fat and ash in various diets, i.e. fish meal, rice bran, polard meal, hydrilla and nittella meal for this fish were analysed by applying $1 \% \mathrm{Cr}_{2} \mathrm{O}_{3}$ in the diet as an internal maker, following the method developed by Watanabe.

Fish of $9.25 \mathrm{~g}$ average weight were stocked at the density of 30 fishes per $60 \mathrm{~L}$ capasity each and reared for 12 days in the wet laboratory.

The result indicated that the values of digestibility of fish meal, and hydrilla meal were better than the other diets $(P<0.05)$. These meals can be used as ingredients for formulating diet of kissing gouramy.

KEYWORDS: digestibility, Helostoma tem minckii.

\section{PENDAHULUAN}

Penelitian mengenai nilai kecernaan berbagai bahan pakan untuk beberapa komoditas ikan masih sangat terbatas. Nilai kecernaan suatu bahan pakan selain ditentukan oleh jenis ikan juga dipengaruhi oleh enzim pencernaan yang ada di dalam tubuh ikan tersebut. Nilai kecernaan sangat menentukan kualitas suatu bahan pakan. Apabila nilai kecernaan rendah, maka pemanfaatan bahan pakan tersebut dalam formula pakan ikan akan sangat terbatas. Penggunaan bahan pakan yang berlebihan akan mempengaruhi nilai efisiensi pakan, tingkat pertumbuhan ikan dan penurunan kualitas air media ikan.

Penggunaan bahan pakan ikan biasanya terdiri atas bahan lokal dan impor. Umumnya bahan pakan impor merupakan bahan utama pakan ikan yang mengandung sumber protein tinggi, dengan harga yang cukup tinggi, misalnya tepung ikan.
Bahan pakan lokal pemanfaatannya masih sangat terbatas, karena kualitas bahan pakan lokal tersebut belum banyak diketahui secara tepat, baik nilai nutrisi maupun nilai kecernaannya.

Ikan tambakan (Helostoma temminckii) adalah komoditas perikanan yang masih kurang diperhatikan oleh masyarakat, sehingga ikan ini agak langka di pasaran, padahal ikan tambakan mempunyai prospek yang cukup baik, karena ikan ini rasanya cukup lezat dan dagingnya tidak banyak berduri.

Penelitian kecernaan bahan pakan terhadap ikan tambakan belum banyak dilakukan, sehingga data penunjang untuk tahap pengembangan selanjutnya masih terbatas. Untuk dapat mengetahui kualitas berbagai bahan pakan lokal, penelitian mengenai nilai kecernaannya terhadap ikan tambakan perlu dilakukan. Penelitian ini merupakan langkah awal untuk mendapatkan

Peneliti pada Balai Penelitian Perikanan Air Tawar 
nilai-nilai kecernaan berbagai bahan pakan lokal sebagai dasar pemikiran dalam membuat formulasi pakan yang berkualitas baik untuk mendukung pertumbuhan dan sintasan ikan secara optimal. Dengan demikian diharapkan dapat menunjang peningkatan produksi ikan tambakan dan dapat menurunkan harga pakan dengan kualitas pakan yang memadai. Pemanfaatan bahan pakan lokal secara optimal perlu diketahui kualitas nutrisinya, melalui penentuan nilai kecernaan bahan pakan tersebut untuk setiap jenis ikan. Tujuan penelitian ini adalah untuk mendapatkan nilai kecernaan bahan pakan tepung ikan, tepung bekatul, tepung pollar, tepung hiydrilla (Hydrilla sp.) dan tepung nitella (Nitella sp.). Penggunaan bahan pakan yang mempunyai nilai kecernaan yang tinggi akan lebih efisien dalam meningkatkan pertumbuhan ikan.

\section{BAHAN DAN METODE}

Penelitian ini dilaksanakan selama 12 hari di laboratorium basah, Bagian Nutrisi Ikan Balai Penelitian Perikanan Air Tawar, Sukamandi. Dua belas akuarium dengan volume air $60 \mathrm{~L}$ digunakan dalam penelitian ini. Sumber air berasal dari air tanah yang dipompa dan ditampung dalam bak aklimatisasi yang disalurkan melalui pipa besi ke dalam akuarium percobaan. Untuk penambahan oksigen dalam air akuarium dipasang aerator. Ikan tambakan dengan bobot awal individu ratarata 9,25 g ditebar sebanyak 30 ekor/akuarium atau 2 ekor/L. Ikan uji berasal dari petani ikan di daerah Parung, Bogor.

Rancangan percobaan yang digunakan adalah Rancangan Acak Lengkap (RAL) dengan lima perlakuan dan satu perlakuan sebagai kontrol. Setiap perlakuan diulang tiga kali. Ada lima bahan pakan perlakuan yang terdiri atas 30\% tepung ikan lokal, 30\% bekatul, 30\% tepung pollar, 30\% tepung hydrilla dan 30\% tepung nitella yang masing-masing dicampur dengan 70\% diet standar (reference diet). Pakan standar adalah pakan yang digunakan sebagai suatu rumusan untuk menghitung nilai kecernaan dari suatu bahan pakan yang ditambahkan. Pada pakan standar yang mengandung protein $35 \%$ ditambahkan 1\% chromium oxide $\left(\mathrm{Cr}_{2} \mathrm{O}_{3}\right)$ sebagai internal marker. Pakan yang diberikan dalam bentuk remah dengan diameter 2 mm untuk memudahkan ikan makan. Komposisi pakan standar dapat dilihat pada Tabel 1 .

Selama percobaan berlangsung, pakan yang diberikan sebanyak 3\% dari populasi ikan dengan waktu pemberian pakan pada pukul 08.00; 13.00 dan 17.00 setiap hari dalam jangka waktu percobaan selama 12 hari. Pengambilan feses (kotoran ikan) dilakukan tiga kali sehari yaitu setiap sebelum pemberian pakan. Segera setelah ikan kenyang dilakukan penyiponan untuk menghindari adanya sisa pakan yang tidak termakan oleh ikan tersebut, sehingga kotoran ikan dapat terpisah dan terlihat jelas. Analisis nilai kecernaan (apparent

Table 1. Komposisi dari pakan standar."

Table 1. Composition of reference diet. *

\begin{tabular}{lc}
\hline \multicolumn{1}{c}{ Kandungan (Ingredient) } & $\%$ \\
\hline Tepung ikan (Fish meal) & 17.0 \\
Tepung kedelai (Soybean meal) & 17.0 \\
Dedak pollar (Pollard wheat) & 14.0 \\
Dedak padi (Rice bran) & 13.8 \\
Tepung hydrilla (Hydrilla meal) & 17.0 \\
Tepung nitella (Nitella meal) & 17.0 \\
Dikalsium Fosfat (Dicalcium phosphate) & 2.0 \\
Campuran mineral (Mineral mix) & 1.0 \\
Campuran Vitamin (Vitamin mix) & 0.2 \\
Kromium oksida (Chromium oxide) & 1.0
\end{tabular}

* Penghitungan nilai kecernaan dengan reference diet pada Tabel 1 didasarkan atas metode yang dilakukan oleh Kamarudin et al. (1989).

Estimation of value of digestibility with reference diet in Table 1 is based on Kamarudin et al. (1989) method. 
digestibility) sesuai dengan rumus Watanabe (1988), sebagai berikut:

Nilai kecernaan $(\%)=\left(1-\frac{a^{1}}{a} \frac{b}{b^{1}}\right) \times 100$

di mana:

$\mathrm{a}=$ Nutrien dalam pakan $(\%)$

$\mathrm{a}^{1}=$ Nutrien dalam feses $(\%)$

$\mathrm{b}=$ Chromium oxide dalam pakan $(\%)$

$\mathrm{b}^{1}=$ Chromium oxide dalam feses $(\%)$

Nilai kecernaan bahan pakan $=\left(\frac{\mathrm{ADT} \cdot 0,7 \mathrm{AD}}{0,3}\right)$

di mana:

$\mathrm{ADT}=\%$ Nilai kecernaan dari pakan

$\mathrm{AD}=\%$ Nilai kecernaan dari pakan standar

Pengamatan kualitas air dilakukan selama 24 jam (selama satu hari) sebelum penelitian dilaksanakan dengan selang waktu pengamatan 6 jam yaitu pukul $06 .^{00} ; 12 .^{00} ; 18 .^{00}$ dan $24 .^{00}$, dengan maksud untuk mengetahui layak dan tidaknya media air tersebut untuk sintasan ikan.

\section{HASIL DAN BAHASAN}

Hasil pengamatan kualitas air sebelum penelitian dapat dilihat pada Tabel 2. Sedang kualitas air selama penelitian adalah suhu air $24,8^{\circ} \mathrm{C}-28^{\circ} \mathrm{C}$; pH air 7,7-9,0; oksigen terlarut (mg/ L) 3,0-7,5; karbondioksida (mg/L) 2,6-6,45; dan N$\mathrm{NH}_{+}$0,015-0,275. Kisaran nilai kualitas air dalam penelitian ini masih berada pada kisaran nilai optimal bagi pertumbuhan ikan.

Analisis proksimat pakan standar (kontrol), campuran pakan standar dan bahan pakan serta feses ikan ditampilkan pada Tabel 3. Sedangkan nilai kecernaan nutrien tepung ikan, bekatul, hydrilla, tepung pollar dan nitella pada pencernaan ikan tambakan ditampilkan dalam Tabel 4 .
Dari hasil analisis proksimat pada Tabel 3 dapat langsung dihitung nilai kecernaan bahan pakan dari tepung ikan, bekatul, tepung pollar. tepung hydrilla, dan tepung nitella dalam pencernaan ikan tambakan pada Tabel 4.

Pada Tabel 3 dapat dilihat perbedaan hasil analisis pakan dan fesesnya. Dari hasil analisis ini ternyata bahwa pada protein dan lemak seluruhnya terjadi penurunan nilai di dalam fesesnya masing-masing, sedangkan pada abu, karbohidrat dan chromium oxide terjadi peningkatan nilai dari masing-masing pakan dalam fesesnya. Hal ini berarti bahwa proses penyerapan/pencernaan protein dan lemak dari pakan yang diberikan pada ikan tambakan dapat berjalan lebih baik dibandingkan dengan penyerapan/pencernaan dari abu maupun karbohidrat yang terdapat dalam pakan. Sebagaimana tertera dalam Tabel 4, nilai kecernaan untuk protein dan lemak setiap bahan pakan yang diberikan mempunyai nilai kecernaan yang lebih baik dibanding dengan nilai kecernaan abu maupun karbohidrat.

Nilai kecernaan untuk bahan kering, ternyata tepung hydrilla lebih baik dibandingkan dengan tepung ikan dan tepung nitella yaitu 95,30\%. Nilai kecernaan protein pada tepung ikan dan tepung hydrilla cukup baik, masing-masing sebesar $96,00 \%$ dan $92,60 \%$. Nilai kecernaan protein tepung ikan pada beberapa spesies umumnya cukup baik seperti pada ikan nila merah untuk protein tepung ikan nilai kecernaannya mencapai $99,45 \%$ (Kamarudin et al., 1989). Demikian pula untuk ikan gurame, ikan jelawat dan grass carp, nilai kecernaan dari protein tepung ikan cukup baik (Law, 1984; Law, 1986; Law et al., 1987). Ikan tambakan termasuk plankton feeder, sehingga ikan ini mempunyai kemampuan yang besar dalam mencerna bahan pakan yang berasal dari bahan nabati. Tepung hydrilla dan tepung nitella berasal dari tanaman air yang terdapat di kolam dan danau. Dari Tabel 3 dapat dilihat, bahwa nilai

Table 2. Kualitas media air sebelum penelitian.

Table 2. Water quality before observation.

\begin{tabular}{|c|c|c|c|c|}
\hline \multirow{2}{*}{$\begin{array}{l}\text { Kualitas Air } \\
\text { Water quality }\end{array}$} & \multicolumn{4}{|c|}{$\begin{array}{c}\text { Waktu Pengamatan } \\
\text { Observation time }\end{array}$} \\
\hline & 06.00 & 12.00 & 18.00 & 24.00 \\
\hline Suhu air (Water temperature) ${ }^{\circ}$ & $24^{0} \mathrm{C}$ & 28 & 26 & 23.8 \\
\hline $\mathrm{pH}$ & 7.8 & 7.8 & 7.8 & 7.8 \\
\hline $\mathrm{O}_{2}$ terlarut $(D O)(\mathrm{mg} / \mathrm{L})$ & 4.5 & 5 & 5 & 5 \\
\hline
\end{tabular}




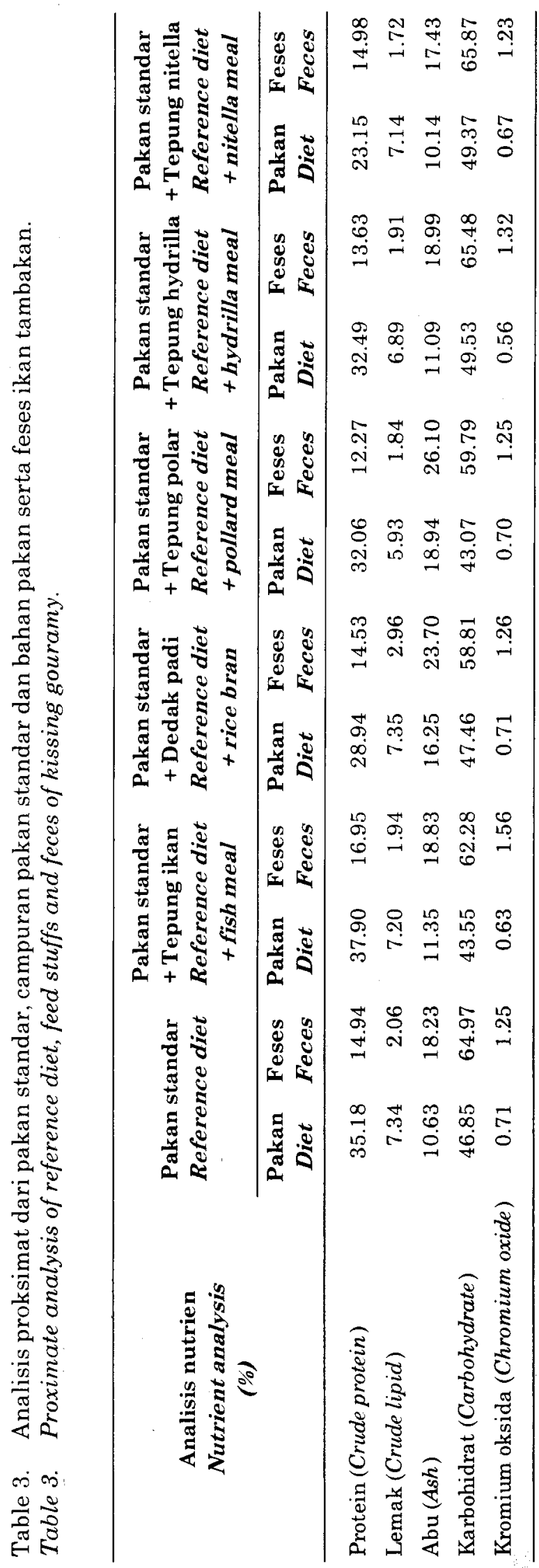


Table 4. Nilai kecernaan dari tepung ikan, bekatul, tepung pollar, tepung hydrilla dan nitella dalam pencernaan ikan tambakan.

Table 4. Apperent digestibilities of fish meal, rice bran, pollard meal, hydrilla and nitella of kissing gouramy.

\begin{tabular}{|c|c|c|c|c|c|}
\hline $\begin{array}{c}\text { Nutrien } \\
\text { Nutrient } \\
\text { (\%) }\end{array}$ & $\begin{array}{c}\text { Tepung } \\
\text { ikan } \\
\text { Fish meal }\end{array}$ & $\begin{array}{c}\text { Dedak } \\
\text { Rice bran }\end{array}$ & $\begin{array}{l}\text { Tepung } \\
\text { pollar } \\
\text { Pollard } \\
\text { meal }\end{array}$ & $\begin{array}{c}\text { Tepung } \\
\text { hydrilla } \\
\text { Hydrilla } \\
\text { meal }\end{array}$ & $\begin{array}{c}\text { Tepung } \\
\text { nitella } \\
\text { Nitella } \\
\text { meal }\end{array}$ \\
\hline Bahan kering (Dry matter) & 82.00 & 84.00 & 84.00 & 95.30 & 72.00 \\
\hline Protein (Crude protein) & 96.00 & 61.63 & 86.00 & 92.60 & 82.60 \\
\hline Lemak (Crude lipid) & 97.00 & 54.70 & 72.40 & 90.30 & 90.30 \\
\hline Karbohidrat (Carbohydrat) & 86.00 & 52.40 & 69.10 & 72.60 & 49.30 \\
\hline $\mathrm{Abu}(A s h)$ & 79.60 & 39.93 & 13.53 & 66.30 & 36.30 \\
\hline
\end{tabular}

kecernaan tepung ikan dan tepung hydrilla lebih baik bila dibandingkan dengan tepung nitella. Pada umumnya nilai kecernaan $80 \%$ atau lebih sudah dianggap baik.

\section{KESIMPULAN}

Tepung ikan dan tepung hydrilla dapat digunakan sebagai bahan pakan dalam formulasi pakan ikan tambakan. Penggunaan tepung nitella masih dapat dimanfaatkan dalam formulasi pakan ikan tambakan, tapi dalam jumlah yang terbatas.

\section{DAFTAR PUSTAKA}

Kamarudin, M.S., Kaliapan, K.M. and Siraj, S.S. 1989. The digestibility of several feedstuffs in red tilapia. In De Silva, S.S. (eds.) Fish Nutrition Research In Asia. Proceedings of The Third Asian Fish Nutrition Network Meeting. Asian Fish. Soc. Spec. Publ.4. Asian Fisheries Society,Manilla, Philippines. 118. 122.
Law, A.T. 1984. Nutritional study of jelawat (Leptobarbus hoeveni Bleeker), fed pelleted feed. Aquaculture 41: 227-233.

Law, A.T. 1986. Digestibility of low-cost ingredients in pelleted feed by grass carp (Ctenopharyngodon idella). Aquaculture 51: 97-103.

Law, A.T., Chong, K.K. and Ang, K.J. 1987. Digestibility of ingredients in a pelleted feed by giant gouramy, Osphronemus gouramy (Lacepede). In Hutagalung, R.I., Chen, C.P., Wan Embong, W.M., Law, A.T. and Sivarajasingam, S. (eds.). Proceedings of the $10^{\text {th }}$ Annual Conference Malaysian Society of Animal Production, 206-207.

Watanabe, T. 1988. Fish Nutrition and Mariculture. Departement of Aquatic Biosciences. Tokyo University of Fisheries. 